\title{
Short-term variations of plasma testosterone concentrations in the European badger (Meles meles)
}

\author{
D. Maurel, A.-M. Laurent and J. Boissin \\ Centre d'Etudes Biologiques des Animaux Sauvages, Centre National de la Recherche \\ Scientifique, Villiers-en-Bois, 79360 Beauvoir-sur-Niort, France
}

\begin{abstract}
Summary. Badgers were sampled once during the sexually inactive season (July-November) and during the breeding season (February-April) and testosterone and dihydrotestosterone (DHT) concentrations were measured by radioimmunoassay after separation by chromatography. Concentrations of both hormones were higher in the breeding than non-breeding season, but the mean ratio of testosterone to DHT was greater in the breeding (14) than in the non-breeding season (7). During the breeding season (March 1979) 18 adult male badgers were bled at 12-min intervals for $3 \mathrm{~h}$ over a period of $24 \mathrm{~h}$. Testosterone concentrations were measured without chromatography. An episodic pattern of release was observed. All the animals exhibited peaks of large amplitude (1-30 ng/ml) which lasted for about $2 \mathrm{~h}$. The great variability in mean testosterone values for each animal $(1-13 \mathrm{ng} / \mathrm{ml})$ could also have been due to differences in individual sexual status.
\end{abstract}

\section{Introduction}

It is now well established for a number of species that testicular function exhibits cyclic activity. Seasonal testosterone variations have been described for several wild hibernating mammals such as hedgehogs (Saboureau \& Boissin, 1978), bats (Racey, 1974; Gustafson \& Shemesh, 1976) and black bears (McMillin, Seal, Rogers \& Erickson, 1976) and non-hibernating animals such as roe deer (Short \& Mann, 1966; Sempéré, 1978), reindeer and caribou (Whitehead \& McEwan, 1973), white-tailed deer (McMillin, Seal, Keenyne, Erickson \& Jones, 1974; Mirarchi, Howland, Scanlon, Kirkpatrick \& Sanford, 1978), red foxes (Joffre \& Joffre, 1975) and moles (Racey, 1978). Maurel, Joffre \& Boissin (1977) have demonstrated seasonal variations in plasma testosterone concentrations, but there was great variability in the individual results. Moreover, high concentrations were sometimes found in animals that were sexually inactive while low values were present in animals exhibiting great sexual activity during the breeding season. Such results may be related to the existence of short-term or diurnal variations.

The purpose of the present work was to determine (1) the relationships between testosterone and dihydrotestosterone concentrations during the breeding season and the sexually inactive season, and (2) whether the badger exhibits a diurnal pattern of testosterone secretion during the breeding season.

\section{Materials and Methods}

\section{Animals}

The adult badgers were obtained from the numerous burrows located in the area of the laboratory (C.E.B.A.S., Chizé forest, western France, $46^{\circ} 19^{\prime} \mathrm{N}, 00^{\circ} 24^{\prime} \mathrm{W}$ ). The animals were 
housed outdoors in individual pens $(2 \times 2 \mathrm{~m})$ with a box in the forest in the vicinity of the laboratory and fed daily with 1-day-old chicks specially hatched in standard farms. Water was always available.

\section{Experiment 1: ratio of testosterone: dihydrotestosterone}

Procedure. The observations were made on 4-7 badgers during the breeding season (February, March, April) and during the sexually inactive season (July, September, October). They were lightly anaesthetized with ether, and blood samples $(10 \mathrm{ml})$ were taken quickly by venepuncture. All samples were heparinized, centrifuged immediately and the plasma stored at $-25^{\circ} \mathrm{C}$ until assayed.

Hormone assay. Testosterone and 5a-dihydrotestosterone (DTH) in plasma samples $(0.4 \mathrm{ml})$ were determined by radioimmunoassays with commercial kits (Biomérieux, France). Each plasma sample was assayed in duplicate. Two internal isotope standards $\left(\left[{ }^{3} \mathrm{H}\right]\right.$ testosterone and $\left.\left[{ }^{3} \mathrm{H}\right] \mathrm{DHT}\right)$ were added to each plasma sample to determine recovery and efficiency of separation. The steroids were extracted twice with $5 \mathrm{ml}$ diethyl ether. The only significant cross-reaction of the testosterone antiserum (immunoadsorbant cellulosic-antitestosterone-3-(O-carboxymethyl)oxime-bovine serum albumin) occurred with $5 \alpha$-dihydrotestosterone which yielded $45 \%$ cross-reactivity. Testosterone and $5 \alpha$-DHT were separated on celite columns. DHT was eluted with iso-octane: ethyl acetate $(94: 6 \mathrm{v} / \mathrm{v})$ and testosterone with iso-octane:ethyl acetate $(80: 20$ $\mathrm{v} / \mathrm{v})$.

For the DHT eluate, the $\left[{ }^{3} \mathrm{H}\right] \mathrm{DHT}$ recovery was consistently $>75 \%(70-90 \%)$ and the $\left[{ }^{3} \mathrm{H}\right]$ testosterone recovery $<2 \%$. For the testosterone eluate, the $\left[{ }^{3} \mathrm{H}\right]$ testosterone recovery was consistently $>90 \%(85-100 \%)$ and the $\left[{ }^{3} \mathrm{H}\right] \mathrm{DHT}$ recovery $<4 \%$. The intra-assay coefficients of variation were $2-5 \%$ for testosterone and $4-10 \%$ for DHT. Inter-assay coefficients of variation were 14 and $18 \%$ respectively.

To test for accuracy, various amounts of testosterone and DHT were added to a reference sample of badger plasma (that used for the intra- and inter-assay tests). Addition of $0.21,0.42$, 0.84 and $1.68 \mathrm{ng}$ testosterone $/ \mathrm{ml}$ plasma and $0.11,0.21,0.42$ and $0.84 \mathrm{ng} \mathrm{DHT} / \mathrm{ml}$ plasma resulted in mean \pm s.e.m $(n=4)$ estimates of $0.22 \pm 0.03,0.36 \pm 0.06,0.98 \pm 0.09$ and $1.91 \pm 0.13 \mathrm{ng}$ testosterone $/ \mathrm{ml}$ and $0.08 \pm 0.02,0.20 \pm 0.05,0.52 \pm 0.08$ and $1.03 \pm 0.15 \mathrm{ng}$ $\mathrm{DHT} / \mathrm{ml}$. Different volumes of the same plasma sample $(0.3,0.4,0.5,0.6 \mathrm{ml})$ were assayed; the values could be plotted as a straight line (testosterone assay, $r=0.98$; DHT assay, $r=0.98$ ) and the lines were described by the equations $y=1.51 x+0.06$ for testosterone and $y=1.28 x+0.03$ for DHT. Sensitivity, determined as the smallest detectable quantity of hormone, was $8 \mathrm{pg}$ testosterone/tube and $10 \mathrm{pg} \mathrm{DHT} /$ tube.

\section{Experiment 2: episodic testosterone secretion in the breeding season}

Procedure. The experiment was carried out in March when the plasma concentration of testosterone is high (Maurel et al., 1977). Every $4 \mathrm{~h}$ (at 10:00, 14:00, 18:00, 22:00, 02:00 and $06: 00 \mathrm{~h}$ ) 3 of the 18 adult males used were simultaneously anaesthetized (fluothane in $\mathrm{O}_{2}$ ) for 3 h. Blood samples $(1.5 \mathrm{ml})$ were taken every $12 \mathrm{~min}$ by venepuncture from a heparinized catheter in the radial or the jugular vein. All samples were heparinized, centrifuged immediately and the plasma stored at $-25^{\circ} \mathrm{C}$ until assayed. Red blood cells from each sample were resuspended in sterile saline solution and reinjected after $1 \mathrm{~h}$ of anaesthesia.

Direct assay of plasma testosterone. This assay differed from that described for Exp. 1 in that: (1) only $\left[{ }^{3} \mathrm{H}\right]$ testosterone was added to each plasma sample $(0.4 \mathrm{ml})$ as the internal isotope standard for recovery of extraction, and (2) there was no separation from DHT on celite columns. Recovery of labelled testosterone from plasma without chromatography on celite columns was consistently $>95 \%(80-100 \%)$. 
All data are presented as the mean \pm 1 s.e.m. and statistical significance of differences was assessed by analyses of variance.

\section{Results}

\section{Seasonal variations of plasma DHT and testosterone}

The results are shown in Table 1 . Testosterone concentrations were low during the sexually inactive season $(1.0 \mathrm{ng} / \mathrm{ml})$ and much higher during the breeding season $(5.2 \mathrm{ng} / \mathrm{ml})$ while plasma DHT values were 0.14 and $0.4 \mathrm{ng} / \mathrm{ml}$ in the non-breeding and breeding months respectively. These plasma testosterone values are similar to those previously obtained for the badger (Maurel et al., 1977). There were, however, wide variations in the concentrations of the two hormones. The percentage of DHT to testosterone in the breeding season was low $(<10 \%)$ and therefore justified direct assay of plasma testosterone without chromatography. The ratio of testosterone to DHT was lower during the sexually inactive season.

Table 1. Plasma concentrations of testosterone and $5 \alpha$-dihydrotestosterone (DHT) in the badger during the breeding season (January-May) and the sexually inactive season (July-November)

\begin{tabular}{llcccc}
\hline Season & Month & $\begin{array}{c}\text { No. } \\
\text { of animals }\end{array}$ & $\begin{array}{c}\text { Testosterone } \\
(\mathrm{ng} / \mathrm{ml})\end{array}$ & $\begin{array}{c}5 \alpha \text {-DHT } \\
(\mathrm{ng} / \mathrm{ml})\end{array}$ & $\begin{array}{c}\text { Testosterone/DHT } \\
\text { ratio }\end{array}$ \\
\hline Breeding & February & 4 & $4.91 \pm 1.96$ & $0.28 \pm 0.08$ & 17.5 \\
& March & 6 & $4.45 \pm 0.93$ & $0.39 \pm 0.02$ & 11.4 \\
& April & 7 & $6.20 \pm 0.87$ & $0.53 \pm 0.02$ & 11.7 \\
\hline Sexually & July & 4 & $0.80 \pm 0.16$ & $0.14 \pm 0.04$ & 5.7 \\
inactive & September & 4 & $1.26 \pm 0.27$ & $0.13 \pm 0.05$ & 9.7 \\
& October & 5 & $0.94 \pm 0.38$ & $0.14 \pm 0.05$ & 6.7 \\
\hline
\end{tabular}

Table 2. Mean ( \pm s.e.m.), minimum and maximum individual testosterone levels during the 3 -h periods of 12-min sampling in the adult male badger during the breeding season

\begin{tabular}{|c|c|c|c|c|}
\hline \multirow{2}{*}{$\begin{array}{c}\text { Start } \\
\text { of sampling (h) }\end{array}$} & \multirow{2}{*}{$\begin{array}{c}\text { Animal } \\
\text { no. }\end{array}$} & \multicolumn{3}{|c|}{ Plasma testosterone conc. $(\mathrm{ng} / \mathrm{ml})$} \\
\hline & & Minimum & Maximum & Mean for the 16 samples \\
\hline $10: 00$ & $\begin{array}{r}8 \\
29 \\
46\end{array}$ & $\begin{array}{l}1.5 \\
1.2 \\
0.49\end{array}$ & $\begin{array}{r}6.4 \\
30.8 \\
11.6\end{array}$ & $\begin{array}{r}2.6 \pm 0.3 \\
12.7 \pm 2.7 \\
4.1 \pm 0.9\end{array}$ \\
\hline $14: 00$ & $\begin{array}{r}3 \\
52 \\
70\end{array}$ & $\begin{array}{l}3.5 \\
1.1 \\
0.96\end{array}$ & $\begin{array}{r}22.4 \\
24 \cdot 5 \\
5.5\end{array}$ & $\begin{array}{r}10.6 \pm 1.4 \\
8.5 \pm 2.2 \\
1.7 \pm 0.3\end{array}$ \\
\hline $18: 00$ & $\begin{array}{r}4 \\
62 \\
74\end{array}$ & $\begin{array}{l}0.42 \\
0.66 \\
0.15\end{array}$ & $\begin{array}{r}14 \cdot 1 \\
7 \cdot 6 \\
5 \cdot 0\end{array}$ & $\begin{array}{c}6.5 \pm 1.1 \\
4.2 \pm 0.6 \\
0.96 \pm 0.35\end{array}$ \\
\hline $22: 00$ & $\begin{array}{r}1 \\
59 \\
72\end{array}$ & $\begin{array}{l}0.81 \\
1.3 \\
1.3\end{array}$ & $\begin{array}{l}12 \cdot 6 \\
22 \cdot 9 \\
16 \cdot 0\end{array}$ & $\begin{array}{l}2.9 \pm 0.9 \\
7.5 \pm 1.7 \\
7.2 \pm 1.3\end{array}$ \\
\hline $02: 00$ & $\begin{array}{r}2 \\
18 \\
73\end{array}$ & $\begin{array}{l}0.29 \\
2.6 \\
0.79\end{array}$ & $\begin{array}{r}3.4 \\
8.9 \\
15.0\end{array}$ & $\begin{array}{l}1.1 \pm 0.3 \\
4.7 \pm 0.5 \\
6.8 \pm 1.4\end{array}$ \\
\hline $06: 00$ & $\begin{array}{c}5 \\
8 \mathrm{~A} \\
25 \\
\end{array}$ & $\begin{array}{l}1.3 \\
0.67 \\
0.67 \\
\end{array}$ & $\begin{array}{r}14 \cdot 5 \\
2 \cdot 1 \\
14 \cdot 8 \\
\end{array}$ & $\begin{array}{l}5.7 \pm 1.2 \\
1.1 \pm 0.1 \\
2.9 \pm 0.9\end{array}$ \\
\hline All animals & & 0.15 & 30.8 & $5 \cdot 1 \pm 0.8$ \\
\hline
\end{tabular}




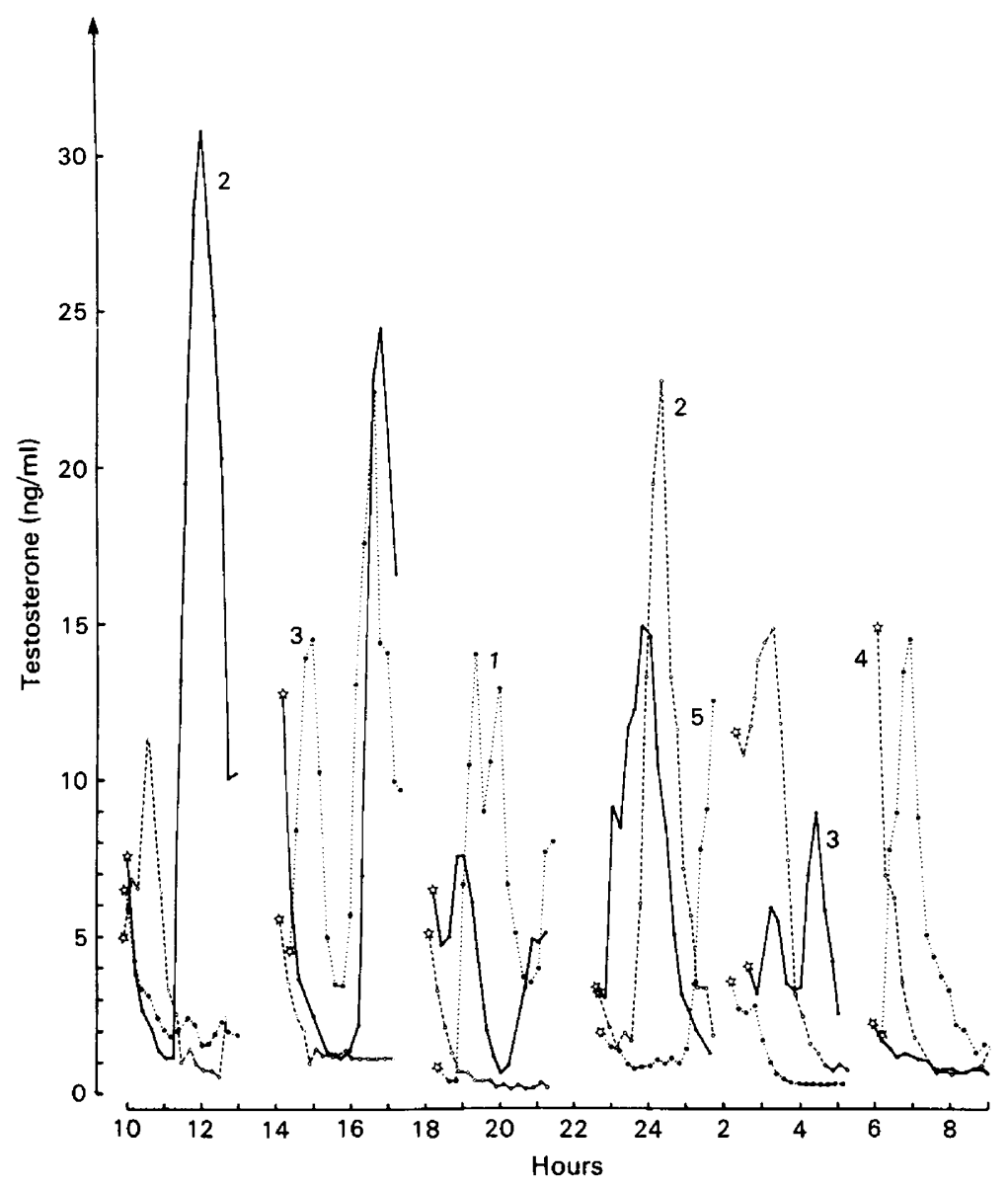

Text-fig. 1. Variations of plasma testosterone concentrations in badgers over a period of $24 \mathrm{~h}$. The first sample taken for each animal is represented by an asterisk. The numbers refer to examples of the different patterns of pulses observed in the 3-h sampling period: (1) a double peak; (2) a single peak; (3) two separate peaks; (4) the end of a peak; (5) the start of a peak.

\section{Short-term variations of plasma testosterone}

The results for 18 badgers are shown in Text-fig. 1. The changes during the 3-h sampling were not similar for each animal. Concentrations rose, fell or remained almost constant but for each animal peaks of secretion could be distinguished. The variations represent a pattern of 'pulses'. Table 2 summarizes the data for each animal during the experiment and shows that even if the mean testosterone concentration for an individual badger is high (e.g. Badger 29) or low (Badger 74) there are values during sampling which show low or high concentrations respectively. The peaks of testosterone concentration were characterized by a great amplitude and a symmetrical profile: the climbing phase had a mean duration of $51 \pm 4$ min and the descending phase of $68 \pm 9$ min (no statistical difference). The mean duration of a peak was approximately $2 \mathrm{~h}$. These peaks occurred irregularly during the $24 \mathrm{~h}$.

\section{Discussion}

The plasma concentrations of DHT in the badger were always low, $0.13-0.53 \mathrm{ng} / \mathrm{ml}$; these values are lower than those found in the rhesus monkey (Robinson, Scheffler, Eisele \& Goy, 
1975) and the ferret (Rieger \& Murphy, 1977), but similar to those in dogs (Folman, Haltmeyer \& Eik-Nes, 1972; Tremblay et al., 1972) and men (Ito \& Horton, 1970; Fiorelli et al., 1976). The fact that the ratio of testosterone to DHT is lower during the sexually inactive season $(5.7-9.7)$ than during the breeding season $(11.4-17.5)$ suggests that the basal secretion level during the non-breeding season is comparatively higher for DHT than for testosterone. Rieger \& Murphy (1977) have shown for the ferret, which belongs to the same family as the badger (i.e. Mustelidae), that ratios of testosterone to DHT ranged from approximately 1 to 4 during the breeding season. In the badger the testosterone-DHT ratio is always higher than in the ferret and it is possible that the testicular secretion of DHT is lower in the badger than in the ferret. In man (Ito \& Horton, 1971) $75 \%$ of the circulating DHT levels result from testosterone metabolism and only $25 \%$ directly from testicular secretion. In the badger the seasonal difference observed in the DHT/testosterone ratio may result from a variation in the secretion of testosterone and DHT by the testis but probably principally from a variation in the metabolic clearance rate of testosterone. We are at present investigating metabolic clearance rates in badgers and other animals to check this possibility.

Changes in testosterone concentrations have been considered as a diurnal rhythm or as pulsatile release; the latter has been demonstrated in men (Alford et al., 1973; Naftolin, Judd \& Yen, 1973; Leymarie, Roger \& Scholler, 1973) and rats (Bartke, Steele, Musto \& Caldwell, 1973). In bulls and rams (Katongole, Naftolin \& Short, 1971, 1974) there are 5-10 peaks of plasma testosterone during the $24 \mathrm{~h}$, unrelated to daylight. There is a pulsatile pattern in testosterone secretion in badgers, with peaks occurring every $3-4 \mathrm{~h}$, and this is the reason for the very large range of testosterone values $(0.15-30.8 \mathrm{ng} / \mathrm{ml})$ obtained. A similar pattern has been demonstrated in the rabbit (Rowe, Shenton \& Glover, 1973; Moor \& YoungLai, 1975), but the amplitude of the peaks is less, $0.5-10.0 \mathrm{ng} / \mathrm{ml}$ (Moor \& YoungLai, 1975).

The great variability in badgers may, however, also be due to individual differences in the sexual status because the animals showed different degrees of testicular activity. Even at the height of the breeding season, the endocrine testicular activity may not be similar for all the animals. The total mean testosterone value for the animals in the present study $(5 \cdot 1 \pm 0.8 \mathrm{ng} / \mathrm{ml}$; $\mathrm{N}=18$ ) is in agreement with the results obtained in March 1976 (Maurel et al., 1977) and in March-April 1978 (Table 1) on animals sampled only once. The lowest testosterone concentrations during the breeding season $(0.15-0.30 \mathrm{ng} / \mathrm{ml})$ are equivalent to those obtained in castrated badgers (Maurel, 1980).

To our knowledge there has been no other work on the short-term testosterone variations in wild mammals, but in the ferret and the mink (Boissin-Agasse \& Boissin, 1979) circahoral changes of large amplitude have been observed during sexual activity. The plasma testosterone peaks are correlated with LH peaks in bulls and rams (Katongole et al., 1971, 1974) and in rabbits (Moor \& YoungLai, 1975) although Wettemann \& Desjardins (1973) did not find such a correlation in rams. The control of episodic testosterone secretion by gonadotrophin (LH and FSH) concentrations by modulation of the amplitude and the number of 'pulses' according to season, as observed in rams (Lincoln, 1976), is now being studied in badgers by examination of the diurnal profile of the testosterone 'pulses' at different times of the year.

This work was supported by the Centre National de la Recherche Scientifique, Paris (A.T.P. Ecophysiologie animale No. 3565). We thank Gérard Laurent for excellent technical assistance.

\section{References}

Alford, F.P., Baker, H.W., Burger, H.G., de Kretser, D.M., Hudson, B., Johns, M.W., Masterson, J.P., Patel, Y.C. \& Rennie, G.C. (1973) Temporal patterns of integrated plasma hormone levels during sleep and wakefulness. II. Follicle-stimulating hormone, luteinizing hormone, testosterone and estradiol. J. clin. Endocr. Metab. 37, 848-854.

Bartke, A., Steele, R.E., Musto, N. \& Caldwell, B.V. 
(1973) Fluctuations in plasma testosterone levels in adult male rats and mice. Endocrinology 92, 1223-1228.

Boissin-Agasse, L. \& Boissin, J. (1979) Variations saisonnières du volume testiculaire et de la testostéronémie chez deux mustélidés: le furet (Mustela furo L.) et le vison (Mustela vison S.). J. Physiol., Paris 75, 227-232.

Fiorelli, G., Borrelli, D., Forti, G., Gonnelli, P., Pazzagli, M. \& Serio, M. (1976) Stimultaneous determination of androstenedione, testosterone and $5-\alpha$ dihydrotestosterone in human spermatic and peripheral venous plasma. J. Steroid Biochem. 7, 113-116.

Folman, Y., Haltmeyer, G.C. \& Eik-Nes, K.B. (1972) Production and secretion of 5 - $\boldsymbol{\alpha}$-dihydrotestosterone by the dog testis. Am. J. Physiol. 222, 653-656.

Gustafson, A.W. \& Shemesh, M. (1976) Changes in plasma testosterone levels during the annual reproductive cycle of the hibernating bat, Myotis lucifugus lucifugus, with a survey of plasma testosterone levels in adult male vertebrates. Biol. Reprod. 15, 9-24.

Ito, T. \& Horton, R. (1970) Dihydrotestosterone in human peripheral plasma. J. clin. Endocr. Metab. 31, 362-368.

Ito, T. \& Horton, R. (1971) The source of plasma dihydrotestosterone in man. $J$. clin. Invest. $\mathbf{5 0}$, 1621-1627.

Joffre, M. \& Joffre, J. (1975) Variations de la testostéronémie au cours de la période prépubère du renardeau et au cours du cycle génital saisonnier du renard mâle adulte (Vulpes vulpes) en captivité. C.r. hebd. Séanc. Acad. Sci., Paris D 281, 819-821.

Katongole, C.B., Naftolin, F. \& Short, R.V. (1971) Relationship between blood levels of luteinizing hormone and testosterone in bulls and the effects of sexual stimulation. J. Endocr. 50, 457-466.

Katongole, C.B., Naftolin, F. \& Short, R.V. (1974) Seasonal variations in blood luteinizing hormone and testosterone levels in rams. J. Endocr. 60, $101-106$.

Leymarie, P., Roger, M. \& Scholler, R. (1973) Variations circadiennes de la testostérone plasmatique chez l'homme adulte normal. Annls Endocr. 34, 719-721.

Lincoln, G.A. (1976) Seasonal variation in the episodic secretion of luteinizing hormone and testosterone in the ram. J. Endocr. 69, 213-226.

Maurel, D. (1980) Variations saisonnières des fonctions thyroïdienne et testiculaire étudiées en relation avec les modalités de l'utilisation du temps ou de l'espace chez le blaireau européen (Meles meles L.) et le renard roux (Vulpes vulpes L.). Thèse de Doctorat ès sciences. Université de Montpellier. p. 240.

Maurel, D., Joffre, J. \& Boissin, J. (1977) Cycle annuel de la testostéronémie et de la thyroxinémie chez le blaireau européen (Meles meles L.). C. r. hebd. Séanc. Acad. Sci., Paris D 284, $1577-1580$.

McMillin, J.M., Seal, U.S., Keenlyne, K.D., Erickson, A.W. \& Jones, J.E. (1974) Annual testosterone rhythm in adult white-tailed deer (Odocoileus virginianus borealis). Endocrinology 94, 1034-1040.
McMillin, J.M., Seal, U.S., Rogers, L. \& Erickson, A.W. (1976) Annual testosterone rhythm in the black bear (Ursus americanus). Biol. Reprod. 15, 163167.

Mirarchi, R.E., Howland, B.E., Scanlon, P.F., Kirkpatrick, R.L. \& Sanford, L.M. (1978) Seasonal variation in plasma LH, FSH, prolactin and testosterone concentrations in adult male whitetailed deer. Can. J. Zool. 56, 121-127.

Moor, B.C. \& YoungLai, E.V. (1975) Variations in peripheral levels of $\mathbf{L H}$ and testosterone in adult male rabbits. J. Reprod. Fert. 42, 259-266.

Naftolin, F., Judd, H.L. \& Yen, S.S.C. (1973) Pulsatile patterns of gonadotropins and testosterone in man: the effects of clomiphene with and without testosterone. J. clin. Endocr. Metab. 36, 285-288.

Racey, P.A. (1974) The reproductive cycle in male noctule bats, Nyctalus noctula. J. Reprod. Fert. 41, 169-182.

Racey, P.A. (1978) Seasonal changes in testosterone levels and androgen-dependent organs in male moles (Talpa europaea). J. Reprod. Fert. 52, 195-200.

Rieger, D. \& Murphy, B.D. (1977) Episodic fluctuation in plasma testosterone and dihydrotestosterone in male ferrets during the breeding season. J. Reprod. Fert. 51, 511-514.

Robinson, J.A., Scheffler, G., Eisele, S.G. \& Goy, R.W. (1975) Effects of age and season on sexual behavior and plasma testosterone and dihydrotestosterone concentrations of laboratoryhoused male rhesus monkeys (Macaca mulatta). Biol. Reprod. 13, 203-210.

Rowe, P.H., Shenton, J.C. \& Glover, T.D. (1973) Testosterone levels in peripheral blood plasma of the rabbit under normal and experimental conditions. Acta endocr., Copenh., Suppl. 177, 124, Abstr.

Saboureau, M. \& Boissin, J. (1978) Seasonal changes and environmental control of testicular function in the hedgehog, Erinaceus europaeus L. In Environmental Endocrinology, pp. 111-112. Eds I. Assenmacher \& D. S. Farner. Springer-Verlag, Berlin.

Sempéré, A. (1978) The annual cycle of plasma testosterone and territorial behavior in the roe deer. In Environmental Endocrinology, pp. 73-74. Eds I. Assenmacher \& D. S. Farner. Springer-Verlag, Berlin.

Short, R.V. \& Mann, T. (1966) The sexual cycle of a seasonally breeding mammal, the roebuck (Capreolus capreolus). J. Reprod. Fert. 12, 337351.

Tremblay, R.R., Forest, M.G., Shalf, J., Martel, J.G. Kowarski, A. \& Migeon, C.J. (1972) Studies of the dynamics of plasma androgens and on the origin of dihydrotestosterone in dogs. Endocrinology 91, 556-561.

Wettemann, R.P. \& Desjardins, C. (1973) Relationship of LH to testosterone in rams. J. Anim. Sci. 36, 212, Abstr.

Whitehead, P.E. \& McEwan, E.H (1973) Seasonal variation in the plasma testosterone concentration of reindeer and caribou. Can. J. Zool. 51, 651-658. 